\title{
Students' mathematical reasoning skills on number pattern using PMRI and collaborative learning approach
}

\author{
Siti Nabila, Ratu Ilma Indra Putri * \\ Department of Mathematics Education, Sriwijaya University, South Sumatra, Indonesia \\ *Correspondence: ratuilma@unsri.ac.id \\ (C) The Author(s) 2022
}

\begin{abstract}
Students need to have good mathematical reasoning skills when learning number pattern material. The use of video media through the PMRI approach and collaborative learning can be applied in learning activities to have good mathematical reasoning skills. This study aims to determine mathematical reasoning skills after implementing the learning process using video media with the PMRI approach and collaborative learning on number pattern material for class VIII students. This research uses a descriptive type of research. The research subjects were students of class VIII.A, SMP Srijaya Negara Palembang, with 25 students (12 males and 13 females) out of a total of 39 students. Data collection techniques are observation, a written test consisting of two test questions, and interviews. The data analysis technique is descriptive. The results obtained from this study are the students' mathematical reasoning skills after the learning process using video media with the PMRI approach and collaborative learning on the number pattern material of grade VIII.A students of SMP Srijaya Negara Palembang are good, with an average value of 68.89. The indicator that appears the most is "submit a conjecture," while the indicator that appears the least is "draw a conclusion." Using video media through the PMRI approach and collaborative learning during learning can make students have good mathematical reasoning skills.
\end{abstract}

Keywords: collaborative learning; mathematical reasoning; PMRI; video media 


\section{Introduction}

Sari et al. (2018) state that reasoning and mathematical material are linked. Based on Permendikbud number 21 of 2016, one of the skill competencies in the 2013 curriculum is reasoning skills. The reasoning was also included in one of the National Council of Teachers of Mathematics (NCTM) process standards in 2000. Reasoning can be used to confirm or disprove conjectures (NCTM, 2000). Mathematical reasoning skills are the skills that enable one to process mathematical thinking in order to arrive at logical conclusions based on existing or suitable methods, concepts, and facts or data (Munawaroh et al., 2019). These skills are essential for students because they can help students generate new ideas, prove and conclude a statement, and solve mathematical problems (Sumartini, 2015). Cahya et al. (2021) also express the importance of mathematical reasoning skills, who state that when students are faced with complex problems, they can be solved quickly. From the explanation above, mathematical reasoning skills are needed to learn mathematics.

Through pattern learning, students can use inductive reasoning to find mathematical relationships (NCTM, 2000). Thus, students can practice their mathematical reasoning skills through learning number patterns (Sari et al., 2018). One of the competencies in learning mathematics is an explanation of patterns in real life and providing advanced assumptions from repetitive patterns (Kemendikbud, 2016). According to NCTM (2000), the two content standards in mathematics related to number patterns are content numbers and operations and algebraic content. Number pattern material is essential for students to learn because it is an essential component of success in mathematics (Diana \& Fauzan, 2018). Number patterns are also included in the quantity content of PISA questions, where the questions are widely applied to real-life (Bidasari, 2017). So, it is expected that students have good mathematical reasoning skills in the number pattern material.

However, in reality, students experience difficulties determining the pattern of the questions given and formulating generalizations from number patterns (Ariyanti \& Setiawan, 2019). When solving number pattern problems, students have not been able to write the formulas for the nth term, which is the basis for solving problems (Sari et al., 2018); and students also have difficulty analyzing questions (Saleh et al., 2021). One of the reasons is the teacher's learning activities, where the activities are still procedural, monotonous, and dominated by teachers (Munawaroh et al., 2019). The teacher also only uses the lecture method (Erissa et al., 2018; Saleh \& Lubis, 2018), and the learning approach is still teacher-centered (Fatimah, 2016). Therefore, the need for an appropriate learning approach to learning number patterns. The learning approach in question should be contextual (Dewi \& Agustika, 2020), namely by providing daily problems so that students are more interested and feel challenged.

A learning approach that emphasizes the presentation of contextual problems is Realistic Mathematics Education (RME) so that during learning activities, students will feel more fun and meaningful (Narmi et al., 2020). It is in line with the thoughts of Rahayu and Putri (2021) that the learning process carried out by involving the context makes the knowledge that students learn meaningfully. RME is known in Indonesia as "The Indonesian Realistic Mathematics Education" (PMRI). According to Meitrilova and Putri (2020), PMRI is one solution to help 
students understand learning materials. The PMRI approach can make learning more interesting because it begins with a real context for students (Putri, 2015). It acts as a bridge from contextual problems to formal mathematics (Trisnawati et al., 2015). According to Zulkardi and Putri (2010), PMRI is a theory based on real problems or student experiences, emphasizing processing skills, collaborating, discussing, and sharing opinions with classmates to find their mathematical concepts to solve problems using mathematics. The principles of PMRI have guided reinvention/progressive mathematizing, didactical phenomenology, and self-developed models, while the characteristics of PMRI are using contextual problems, using models, student contributions, interactivity, and is integrated with other learning topics (Zulkardi \& Putri, 2010). The PMRI approach is one of the active and innovative approaches (Salsabilla, 2020). In PMRI learning, as a result of interaction with the environment, students become individuals (subjects) who have experience and knowledge (Munir \& Sholehah, 2020), while the teacher is only a guide and facilitator (Lisa, 2020).

In the 21st-century, by improving the curriculum following the demands of 21 st-century competencies, education is challenged to produce human resources that can create economic and social order (Sumantri, 2019). The hope is that teachers and students have 21st-century skills, skills, and competencies: collaborative skills, critical thinking, communication skills, and creativity and innovation skills (Sumantri, 2019). According to Rahmawati (2016), through 4C, there will be an increase in the quality of Indonesian education.

One of the 4Cs, namely collaborative, is where students will be actively involved in small groups during the learning process (Septikasari \& Frasandy, 2018). Collaborative learning involves two or more students who are together in groups and provide information, knowledge, ideas, and experiences to increase the understanding of all group members (Deswita \& Niati, 2020). Collaborative learning activities consist of sharing and jumping lessons (Wikanta, 2017). Students who do not understand this activity must dare ask for help from friends who already understand by saying, "Please teach me" (Sato, 2014). The purpose of collaborative learning is for students to be active in groups and create student-centered learning situations (Inah \& Pertiwi, 2017). Thus, the PMRI approach and collaborative learning can be applied together to create more enjoyable learning for students.

In addition to collaborative learning, technology is also progressing very rapidly in the 21 st century, so that it will be advantageous in the field of education (Isti'adah et al., 2020). It is evidenced by the increasing use of technology-based learning media to support the course of learning activities (Firmadani, 2020). One of which is video media, which includes the type of audio-visual media, namely media that uses the senses of hearing and sight, so that when participating in learning can make students do not feel bored and feel happy (Hadi, 2017). Video media can also bring up students' creative ideas because the visualization is moving images and sound (Febriani, 2017). It is not only used as a tool in learning activities but video media can also be used as a messenger or information (Aeni \& Yuhandini, 2018).

When the learning process uses collaborative learning, students are formed into groups of four to complete tasks individually in groups. Then, a video media is given that contains the problems of sharing tasks and jumping tasks (Wikanta, 2017). This problem is related to real 
problems, so this is in line with the understanding of PMRI, which is a theory based on real problems (Zulkardi \& Putri, 2010). According to Rahayu and Putri (2021), the learning process involving the context makes students learn meaningfully. In sharing tasks and jumping tasks, students who do not understand are required to ask for help from their friends who understand by saying, "Please teach me" (Sato, 2014).

Students need to have good mathematical reasoning skills when learning number pattern material. The use of video media through the PMRI approach and collaborative learning can be applied in learning activities to have good mathematical reasoning skills. A previous study on the PMRI approach to number pattern material by Octriana et al. (2019) to see mathematical reasoning skills and research by Situmorang et al. (2020) is about the analysis of HOTS questions. However, previous studies have not used video media. Therefore, researchers are interested in researching "Students' mathematical reasoning skills on number pattern using PMRI and collaborative learning approach". This study aims to determine mathematical reasoning skills after implementing the learning process using video media with the PMRI approach and collaborative learning on number pattern material for class VIII students.

\section{Methods}

This study uses a descriptive type of research to describe the description of mathematical reasoning skills on number pattern material using video media through the PMRI approach and collaborative learning in class VIII students. The subjects of this study were students of class VIII.A of SMP Srijaya Negara Palembang in the odd semester of the 2021/2022 academic year, totaling 25 students (12 males and 13 females) out of a total of 39 students. The instruments used were an observation sheet, a written test consisting of two test questions, and an interview guide sheet. There are three indicators used in this study (see Table 1).

Table 1. Indicators of mathematical reasoning skills

\begin{tabular}{ll}
\hline \multicolumn{1}{c}{ Indicator } & \multicolumn{1}{c}{ Descriptor } \\
\hline Submit a conjecture & $\begin{array}{l}\text { Able to make assumptions about patterns that might } \\
\text { be formed }\end{array}$ \\
\hline $\begin{array}{l}\text { Finding patterns or properties of } \\
\text { mathematical phenomena to make a } \\
\text { generalization }\end{array}$ & $\begin{array}{l}\text { Able to find the right pattern to make general } \\
\text { equations or generalizations }\end{array}$ \\
\hline Draw a conclusion & $\begin{array}{l}\text { Able to make conclusions that are in accordance } \\
\text { with the problem and can be accepted by reason }\end{array}$ \\
\hline
\end{tabular}

In this study, there are three stages: namely: (1) the preparation stage, whereby the researcher prepares research instruments and learning tools, observes schools, validates and revises, and manages research permits; (2) the implementation stage, which consists of two meetings where the first meeting is a learning process using video media with PMRI and collaborative learning, while the second meeting is working on test questions; and (3) the last stage, where the researchers analyze the results of the data from the observation sheets, tests, and interviews. Then, the researcher will describe the data results and conclude. Finally, the researcher will prepare a written research report. 
There are three data collection techniques: observation during learning, mathematical reasoning skill test questions, and interviews with students. In this study, observations were carried out by direct observation of student activities and video recordings. There are two questions in the form of descriptions for the test questions. It is easier for researchers to see indicators of students' mathematical reasoning skills that arise from their answers. One male and two females were interviewed to find out more about the students' answers from working on test questions.

The instrument validation has been carried out with the help of a Mathematics Education Lecturer at Sriwijaya University who is an expert in this research and two mathematics teachers who teach at SMP Srijaya Negara Palembang. The validation result is that there must be 2 test questions gradually from level 2 to level 3, including learning objectives. Researchers have also conducted one-to-one and small group trials to determine the practicality of the test questions.

In this study, descriptive methods were used to analyze observation data, namely describing and describing student activities during learning. To analyze student test results, researchers checked student answers by giving scores based on predetermined assessment guidelines. The following table 2 is scoring guidelines.

Table 2. Scoring guidelines

\begin{tabular}{cl}
\hline Score & \multicolumn{1}{c}{ Scoring Indicator } \\
\hline 4 & Perfect answer, the solution is given completely and correctly \\
\hline 3 & The answer is correct, but the solution given has one significant error \\
\hline 1 & $\begin{array}{l}\text { The answer is almost correct, but the solution provided contains more than one } \\
\text { significant error/shortcoming }\end{array}$ \\
\hline 0 & $\begin{array}{l}\text { Wrong answer, the solution is not completed in its entirety but contains at least } \\
\text { one correct argument }\end{array}$ \\
\hline
\end{tabular}

Then the score obtained will be converted into a value, and then the category of the students' mathematical reasoning skills will be determined based on the Table 3 below.

Table 3. Category of qualitative value of mathematical reasoning skills

\begin{tabular}{cc}
\hline Score & Category \\
\hline $81-100$ & Very Good \\
$61-80$ & Well \\
$41-60$ & Enough \\
$21-40$ & Not Enough \\
$0-20$ & Very Less \\
\hline
\end{tabular}

Then, the frequency of each category of students' mathematical reasoning skills will be obtained, and the average value will be found using the formula for the average group data. The average value will be converted back to table 3 to categorize the students' mathematical reasoning skills. The results of the interview data from this study were analyzed using a descriptive method, namely changing the recorded interview results into the form of written interview transcripts. 


\section{Results}

At the first meeting, students were given contextual questions (sharing task and jumping task) through video media, while at the second meeting, students were given two essay test questions.

\section{Sharing task}

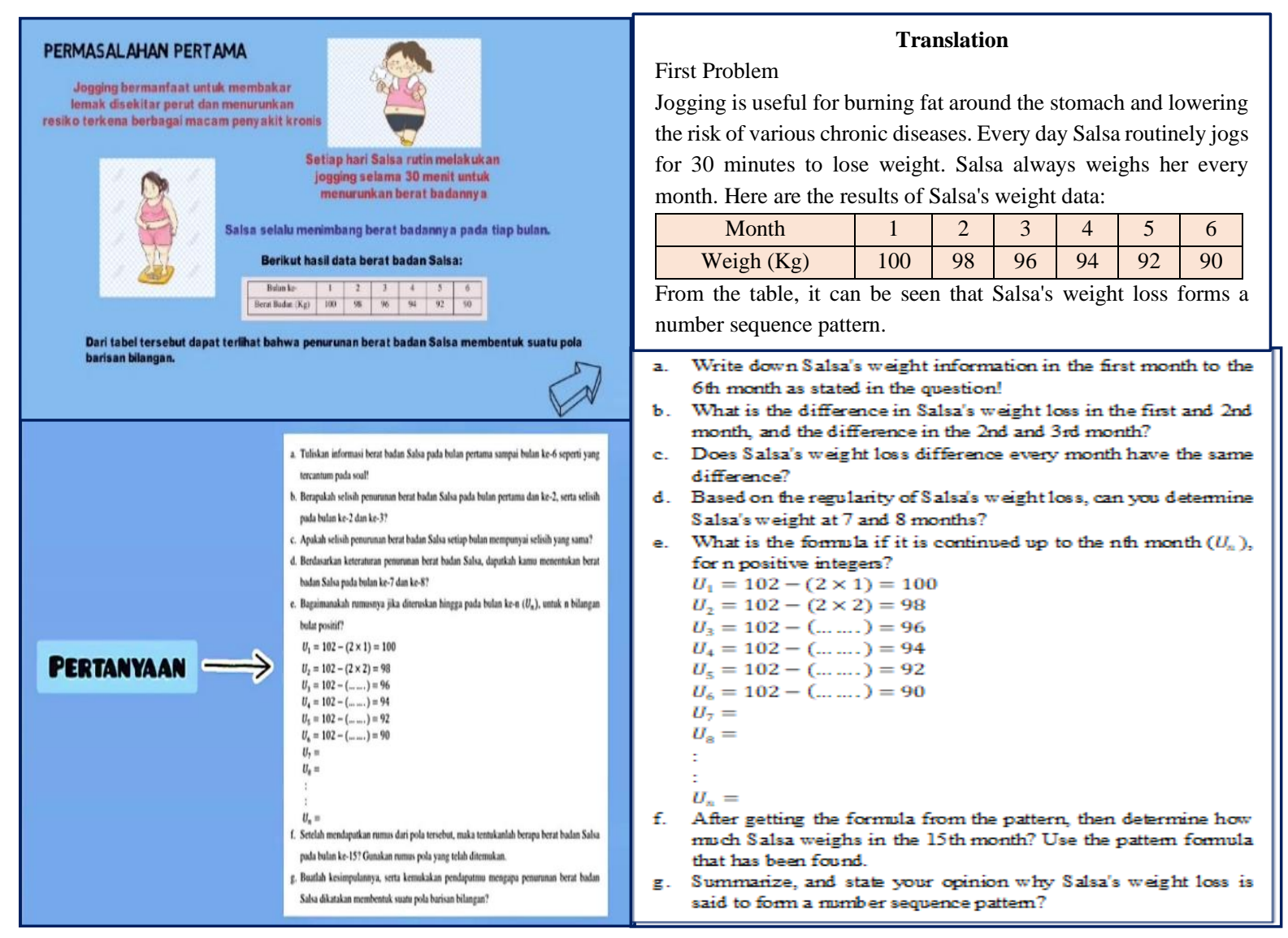

Figure 1. First problem (sharing task)

The context used in task sharing is closely related to real life, namely the context of weight loss. In this problem, students are given tier questions so that it is easier for them to solve. The following is the answer of one of the students from group 3. 


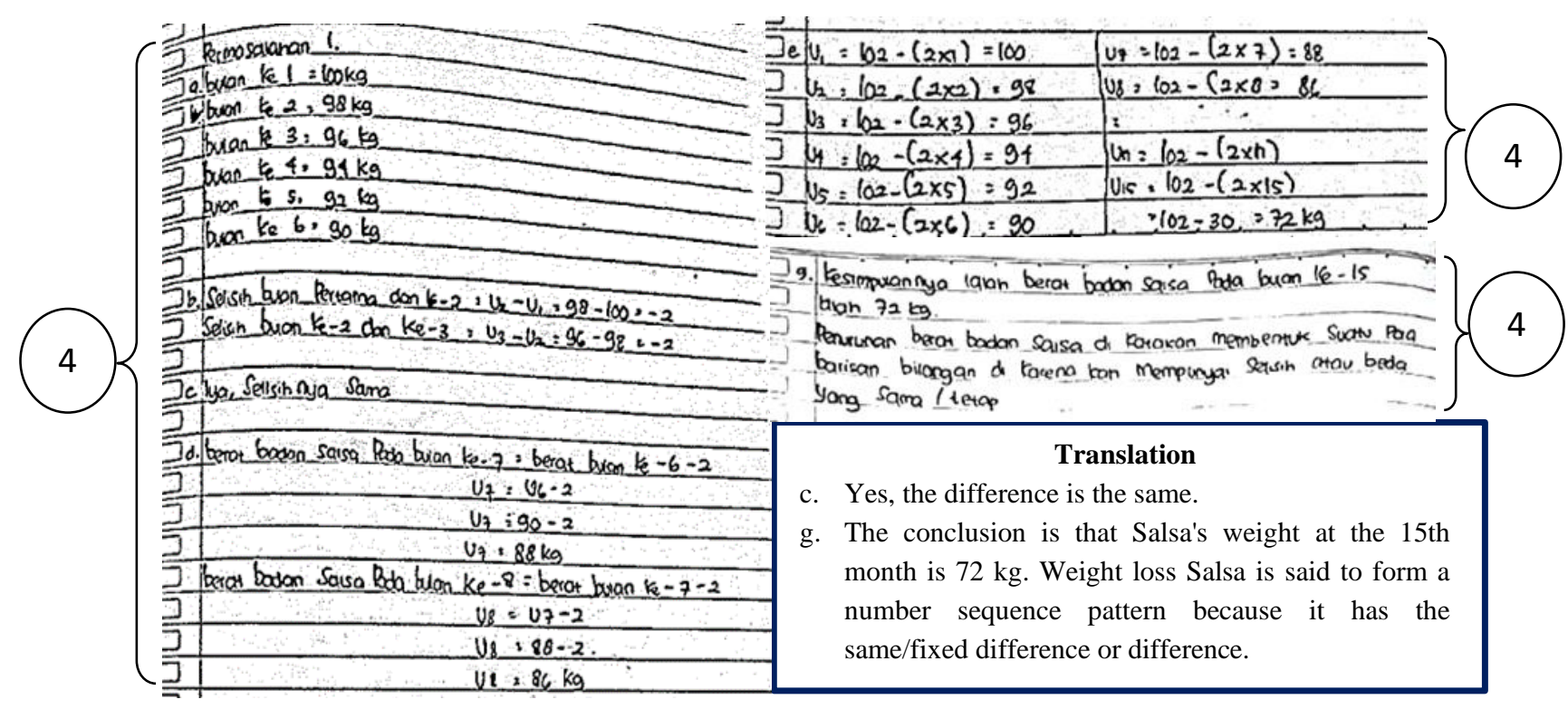

Figure 2. Answer sharing task (group 3)

The student has brought up the three indicators of mathematical reasoning skills perfectly, so that he gets a score of 4 on each indicator. So, the student gets a maximum score of 12 . The method used by group 3 to determine the difference is not the same as that of group 6 , but the difference obtained remains the same. Here's the answer:

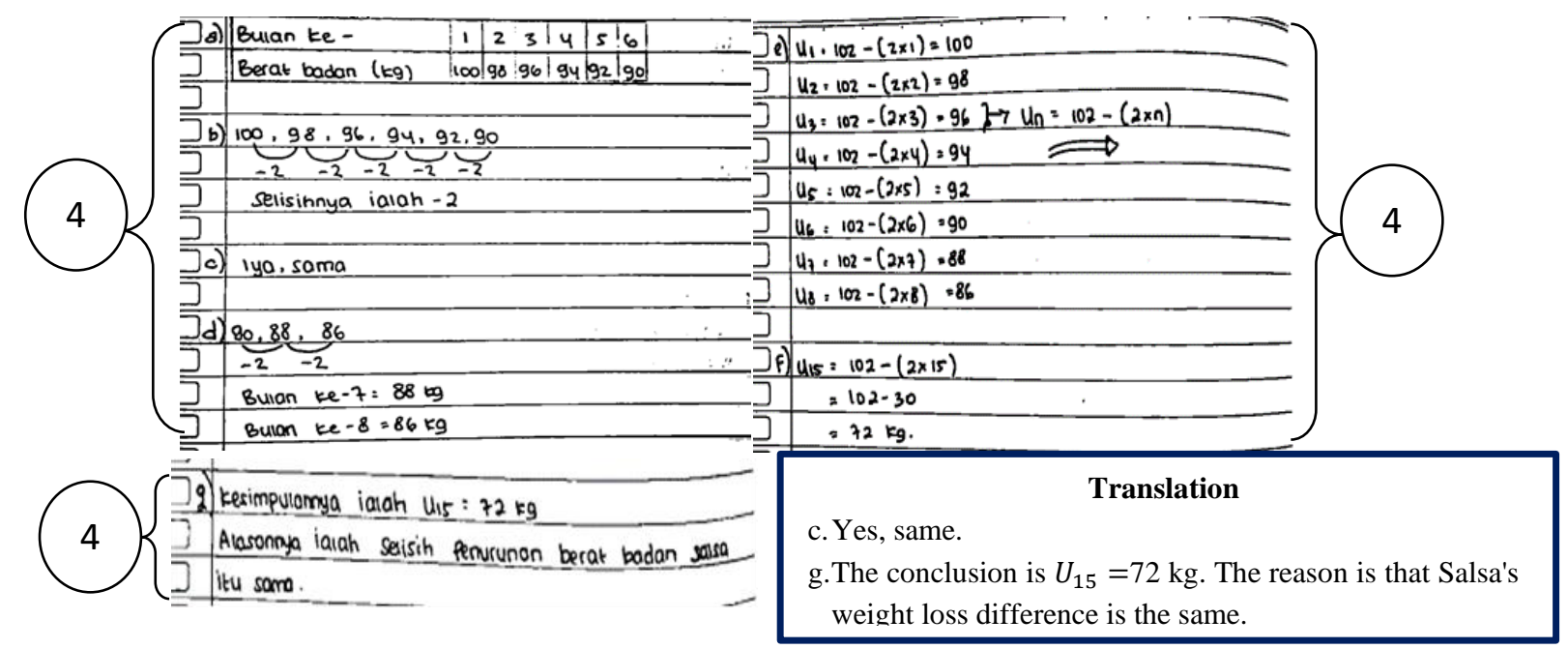

Figure 3. Answer sharing task (group 6)

From the student's answer, it can be seen that she has brought up all three indicators of mathematical reasoning skills perfectly, so that he gets a score of 4 on each indicator. So, the maximum score is 12 . 


\section{Jumping task}

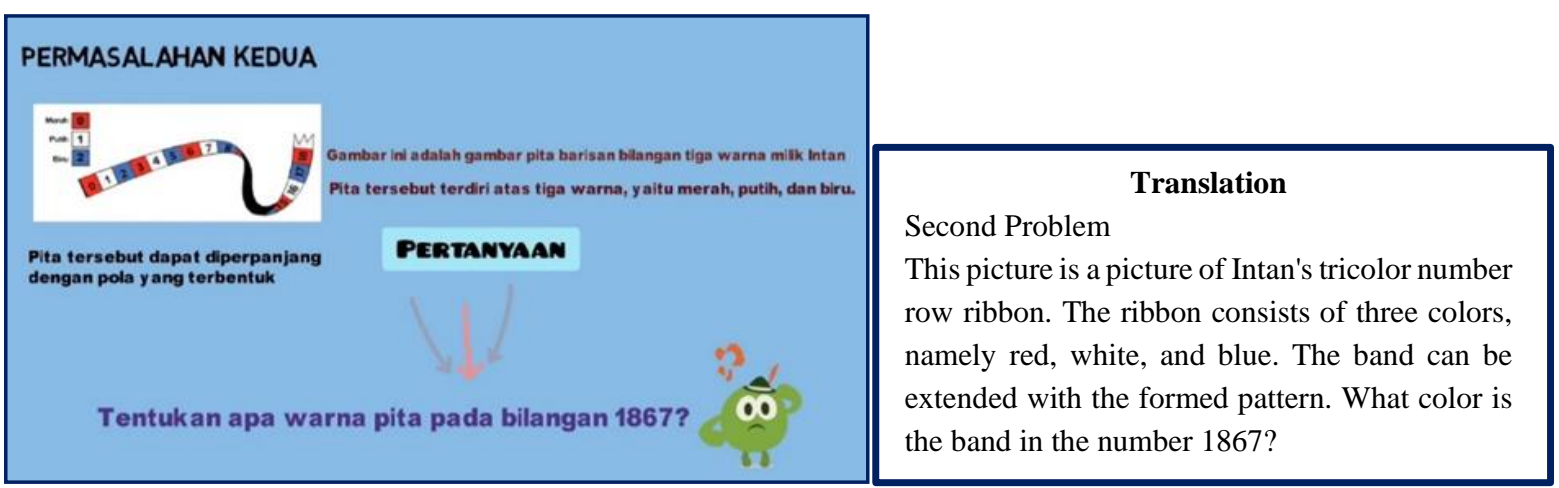

Figure 4. Second problem (jumping task)

For the jumping task, there is one problem with the context of the three-colored ribbon that needs to be solved. The second problem (jumping task) is a problem with a higher level of difficulty than the first problem (sharing task). There are only 2 groups who can answer correctly on the second problem (jumping task). The following is the answer of one student from group 1.

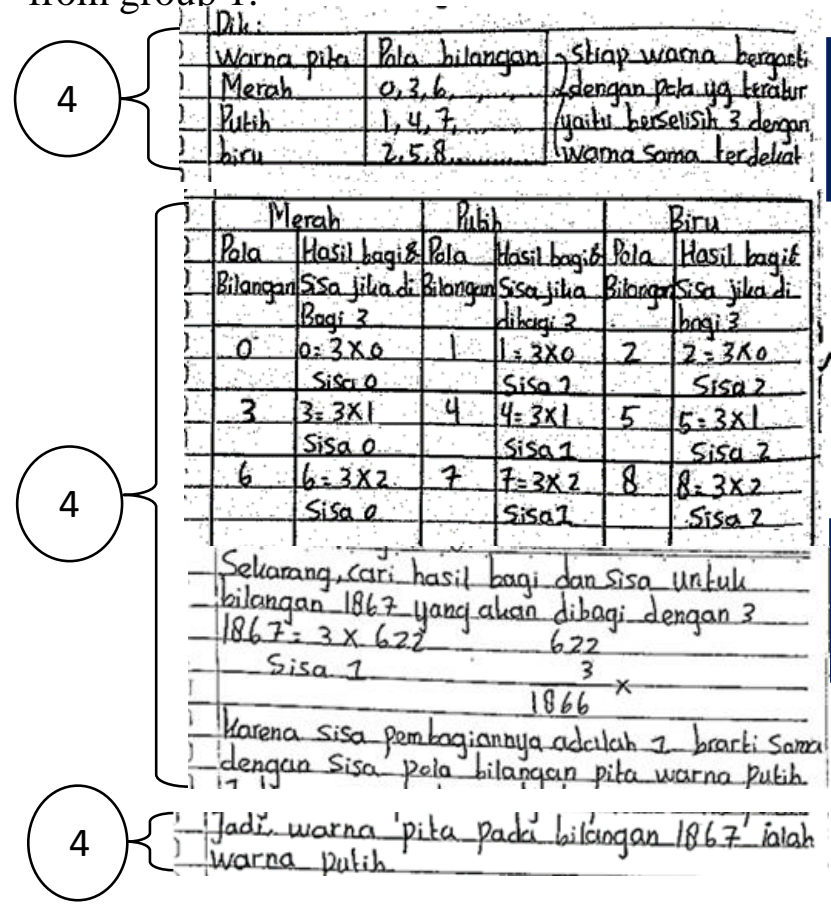

Figure 5. Answer jumping task (group 1)

The student has brought up the three indicators of mathematical reasoning skills perfectly to get a score of 4 on each indicator. So, the student gets a maximum score of 12. The steps used in group 1 were not the same as in group 3, but they still got the same answer. Here is the answer (Figure 6). 


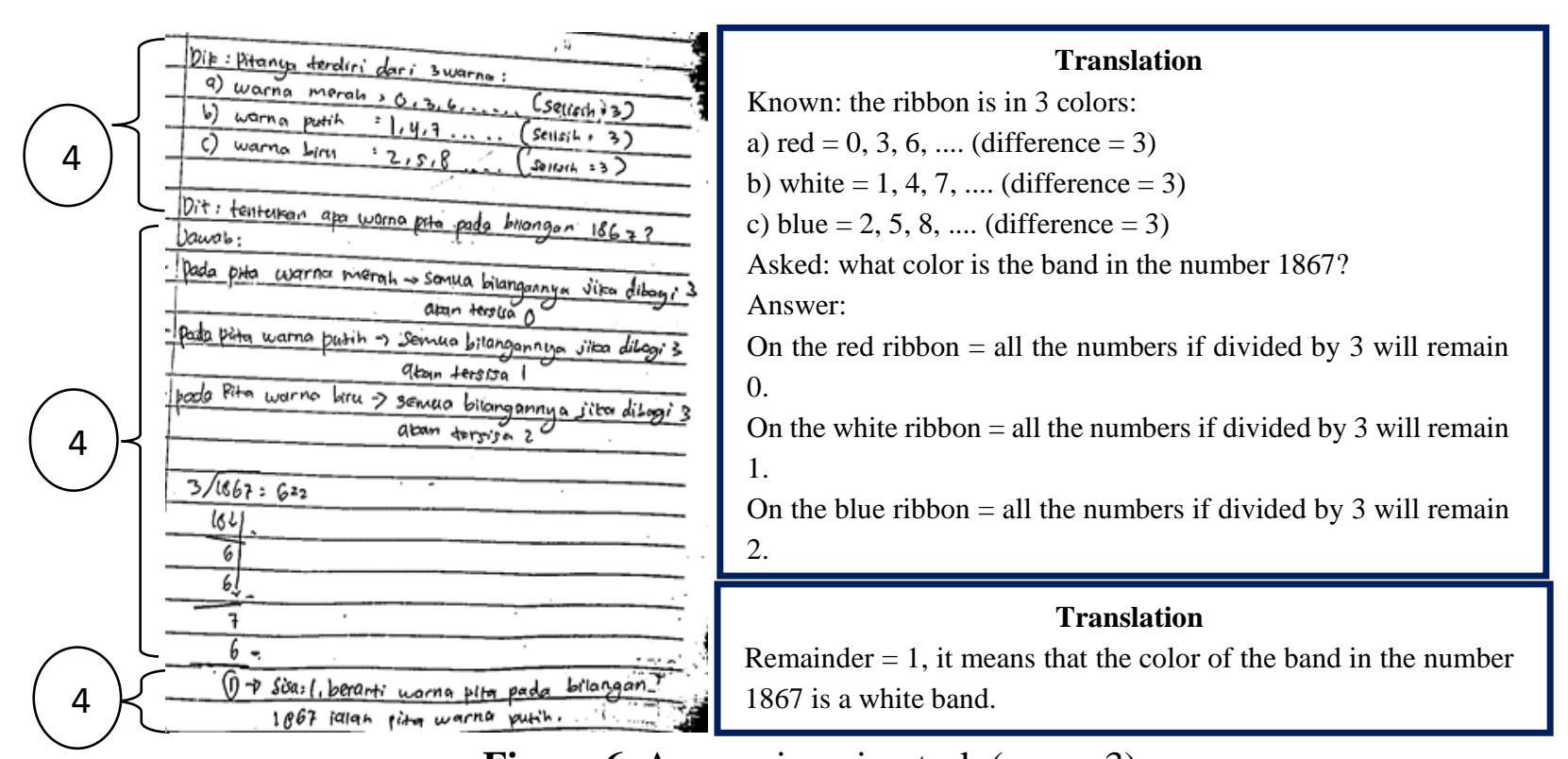

Figure 6. Answer jumping task (group 3)

From the student's answer, it can be seen that she has brought up all three indicators of mathematical reasoning skills perfectly, so that he gets a score of 4 on each indicator. So, his score is 12 .

\section{Test question number 1}

1) Migrasi burung merupakan pergerakan populasi burung yang terjadi pada waktu tertentu setiap tahun, dari tempat berbiak menuju tempat mencari makan selama iklim di tempat berbiaknya itu tidak memungkinkan.

Seorang peneliti migrasi burung yang bernama Alex mencatat pergerakan burung seperti berikut ini: baris pertama terdapat satu ekor burung, baris kedua terdapat tiga ekor burung, baris ketiga terdapat lima ekor burung, baris keempat terdapat tujuh ekor burung, dan seterusnya dengan pola yang sama.

Tentukan berapa banyak burung pada baris ke-20!

\section{Translation}

Bird migration is the movement of bird populations that occur at certain times of the year, from breeding sites to foraging areas as long as the climate in their breeding areas does not allow. A bird migration researcher named Alex recorded bird movements as follows: in the first row there was one bird, the second row had three birds, the third row had five birds, the fourth row had seven birds, and so on in the same pattern. Determine how many birds are in the 20th row!

Figure 7. Test question number 1

For the first test question, where students are asked to determine the number of birds in the 20th row. The answers from the three students regarding question number 1 are as follows in Figure 8.

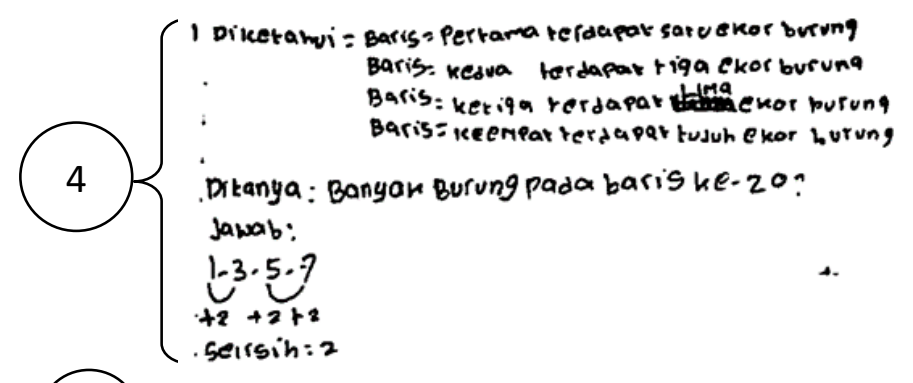

Translate
Known: the first row there was one bird
the second row had three birds
the third row had five birds
the fourth row had seven birds
Asked: Many birds in the 20th row?

$1 \cdot 3,5,7,9,11,13 \cdot 15,17,19,21,23,25,27,29 \cdot 31 \cdot 33,35$

Figure 8. Answers to number 1 of MF students' test questions 
Based on the results of MF students' answers, he has submitted a conjecture to get a score of 4 on this indicator. However, he is still not quite right on the indicator of finding patterns or properties of mathematical phenomena to generalize. He gets answers is 35 while the correct answers are 39, so he gets a score of 1 . It is supported when interviewed, and he also admitted that he was wrong in writing answers because the time was limited. Then the MF students did not come up with indicators to conclude. So, MF students only got a score of 5 for test question number 1 .

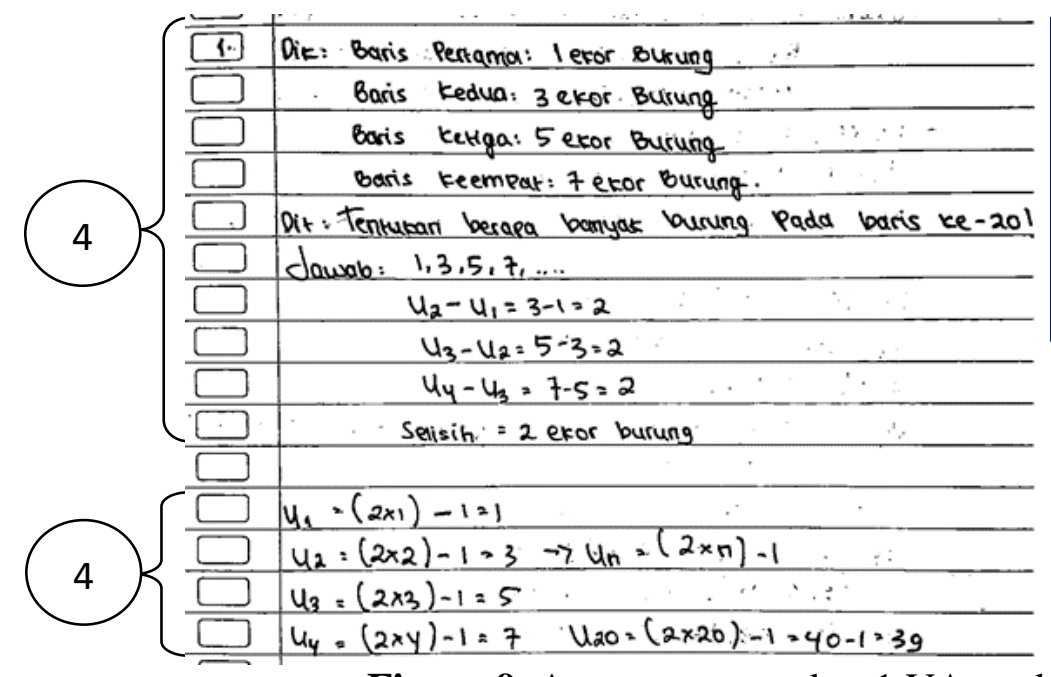

\begin{tabular}{|c|}
\hline Translate \\
Known: \\
First row $=1$ bird \\
Second row $=3$ bird \\
Third row $=5$ bird \\
Fourth row $=7$ bird \\
Asked: Determine how many \\
birds are in the 20 th row!
\end{tabular}

Figure 9. Answers to number $1 \mathrm{VA}$ student test questions

Based on these answers, it can be seen that the VA students already understand and can solve problem number 1. It's just that he forgot to write the conclusions because of the limited time given to do it. So, VA students get a score of 8 .

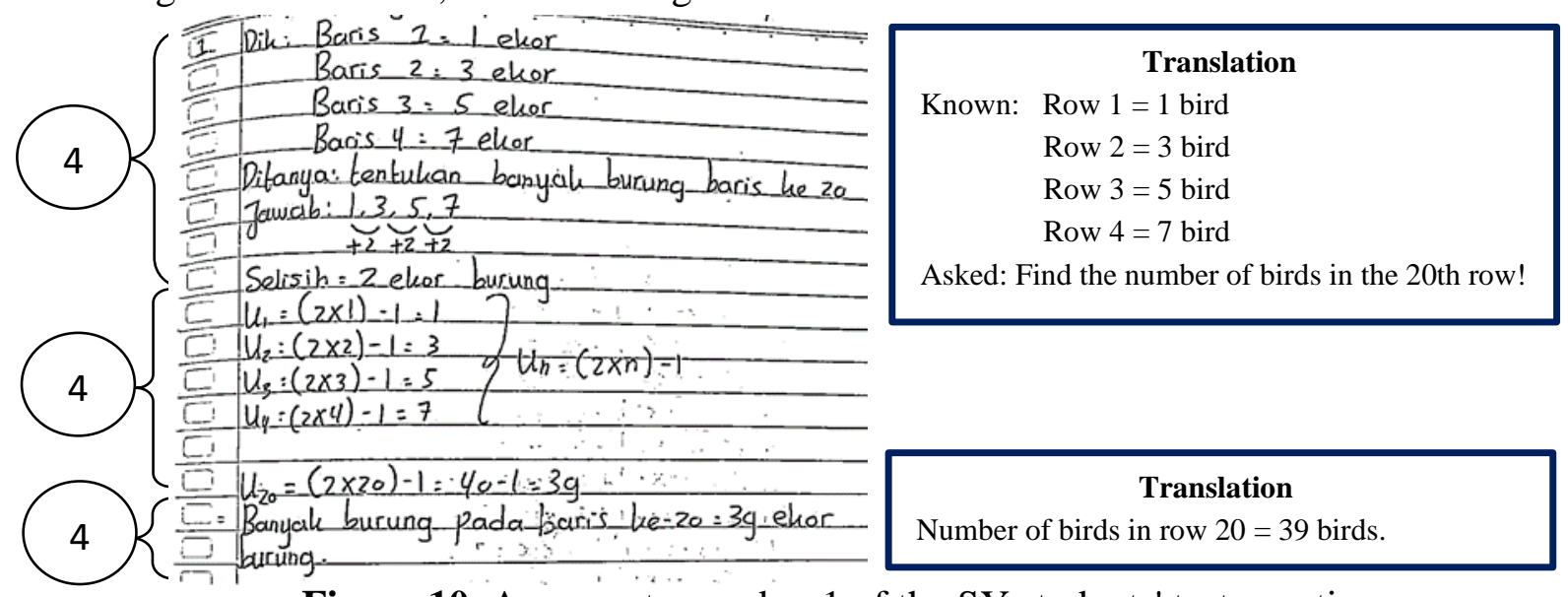

Figure 10. Answers to number 1 of the SY students' test questions

When interviewed, SY students seemed to have understood question number 1 and could solve it correctly. SY students have brought up the three indicators of mathematical reasoning skills perfectly. So, SY students get the maximum score for the number one test question, which is 12 . 


\section{Test question number 2}

2) Setiap hari Siska diberi uang jajan oleh Ayahnya dan ia selalu menyisihkan uangnya untuk membeli sebuah handphone. Pada bulan pertama ia menyisihkan uangnya sebesar Rp 2.000,00/hari, pada bulan kedua ia menyisihkan uangnya sebesar Rp 3.000,00/hari, pada bulan ketiga ia menyisihkan uangnya sebesar Rp 4,000,00/hari, dan seterusnya sampai 10 bulan (dengan perhitungan 1 bulan = 30 hari). Apakah uang hasil tabungan Siska selama 10 bulan cukup untuk membeli handphone seharga Rp 2,000.000,00?

Translate
Every day Siska is given pocket money by her father
and she always sets aside money to buy a cellphone.
In the first month he sets aside Rp. $2,000.00$ /day, in
the second month he sets aside Rp. $3,000.00$ /day, in
the third month he sets aside Rp. $4,000.00 /$ day, and so
on for up to 10 months (by calculating 1 month = 30
days). Is the money that Siska saved for 10 months is
enough to buy a cellphone for Rp. $2,000,000.00$ ?

Figure 11. Test question number 2

For the second test item where students are asked to find out whether the money Siska has saved for 10 months is enough to buy a cellphone for Rp. 2,000,000.00. The answers from the three students regarding question number 2 are as follows (see Figure 12).

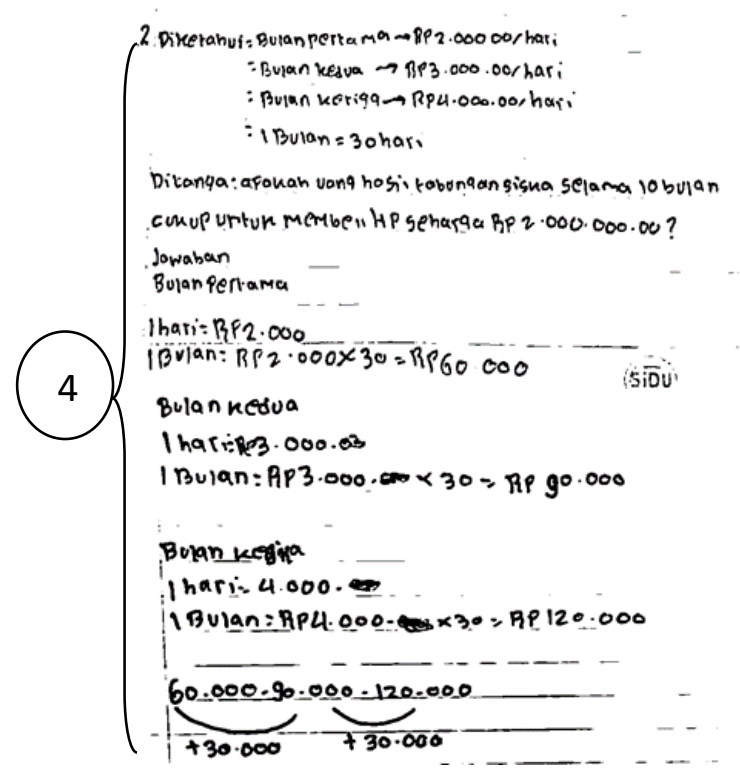

Translate
Known: First month $=$ Rp. $2,000.00 /$ day
$\quad$ Second month $=$ Rp. $3,000.00 /$ day
Third month $=$ Rp. $4,000.00 /$ day
$\quad 1$ month $=30$ days

Figure 12. Answers to number 2 of MF students' test questions

When interviewed, MF students said that not complete it because they did not have enough time to do it. However, MF students have come up with indicators of making conjectures ideally, so they get a score of 4 . So, MF students only get a score of 4 for test question number two. 


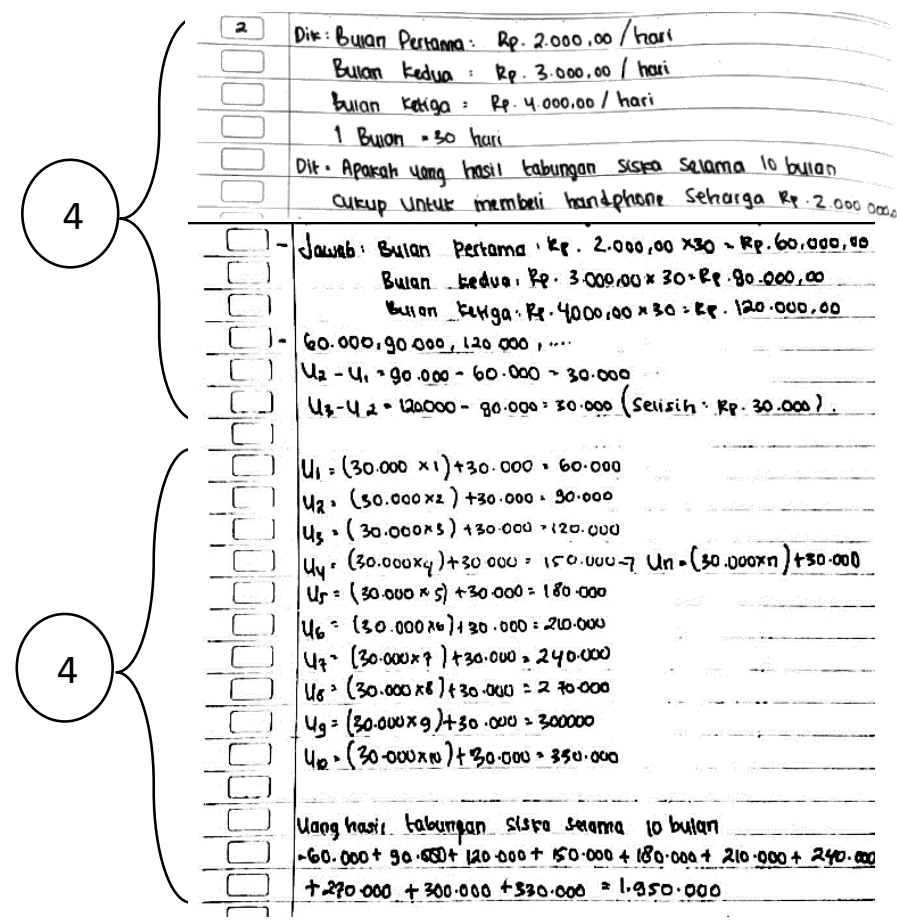

\begin{tabular}{|c|c|}
\hline \multicolumn{2}{|r|}{ Translation } \\
\hline Known: & First month $=$ Rp. $2,000.00 /$ day \\
\hline & Second month $=$ Rp. 3,000.00/day \\
\hline & Third month $=$ Rp. 4,000.00/day \\
\hline & 1 month $=30$ days \\
\hline \multicolumn{2}{|c|}{$\begin{array}{l}\text { Asked: Is the money that Siska saved for } 10 \text { months } \\
\text { is enough to buy a cellphone for Rp. } 2,000,000.00 ?\end{array}$} \\
\hline \multicolumn{2}{|c|}{ Answer: } \\
\hline \multicolumn{2}{|c|}{ First month $=$ Rp. $2,000.00 \times 30=$ Rp. $60,000.00$} \\
\hline \multicolumn{2}{|c|}{ Second month $=$ Rp. $3,000.00 \times 30=$ Rp. $90,000 \cdot 00$} \\
\hline \multicolumn{2}{|c|}{ Third month $=$ Rp. $4,000.00 \times 30=$ Rp. $120,000.00$} \\
\hline
\end{tabular}

Figure 13. Answers to number 2 of VA students' test questions

Based on these answers, it can be seen that the VA students already understand and can solve problem number 2. It's just that he forgot to write the conclusions because of the limited time given to do it. So, VA students get a score of 8 .

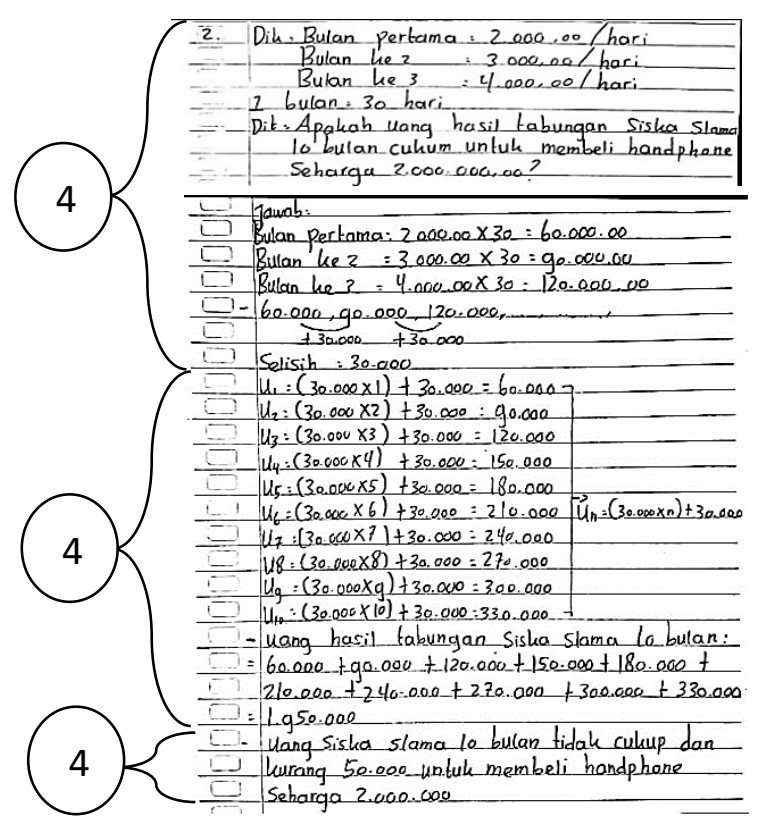

\begin{tabular}{|c|c|c|}
\hline & $\begin{array}{l}\text { Known: } \\
\text { Asked: } \\
\text { to buy a } \\
\text { Answer: } \\
\text { First mo } \\
\text { 2nd mon } \\
\text { 3rd mon }\end{array}$ & $\begin{array}{l}\text { Translation } \\
\text { First month }=\text { Rp. } 2,000.00 / \text { day } \\
\text { 2nd month }=\text { Rp. } 3,000.00 / \text { day } \\
\text { 3rd month }=\text { Rp. } 4,000.00 / \text { day } \\
1 \text { month }=30 \text { days } \\
\text { s the money that Siska saved for } 10 \text { months is enough } \\
\text { cellphone for Rp. } 2,000,000.00 ? \\
\text { nth }=\text { Rp. } 2,000.00 \times 30=\text { Rp. } 60,000.00 \\
\text { th }=\text { Rp. } 3,000.00 \times 30=\text { Rp. } 90,000.00 \\
\text { th }=\text { Rp. } 4,000.00 \times 30=\text { Rp. } 120,000.00\end{array}$ \\
\hline & $\begin{array}{l}\text { Siska's s } \\
150,000 \\
+330,00 \\
\text { Siska's n } \\
\text { to buy a }\end{array}$ & $\begin{array}{l}\text { Translation } \\
\text { avings for } 10 \text { months }=60,000+90,000+120,000+ \\
+180,000+210,000+240,000+270,000+300,000 \\
0=1,950,000 \\
\text { loney for } 10 \text { months is not enough and less than } 50,000 \\
\text { cellphone for } 2,000,000\end{array}$ \\
\hline
\end{tabular}

Figure 14. Answers to number 2 of the SY students' test question

When interviewed, SY students seemed to have understood question number 2 and were able to solve it correctly. SY students have brought up the three indicators of mathematical reasoning skills perfectly. So, SY students get the maximum score for the number two test question, which is 12 . 
Table 4. The emergence of indicators of mathematical reasoning skills

\begin{tabular}{lcc}
\hline \multicolumn{1}{c}{ Indicator } & \multicolumn{3}{c}{ Total Eligible Students } \\
& Test Question Number 1 & Test Question Number 2 \\
\hline Submit a conjecture & 25 & 23 \\
\hline $\begin{array}{l}\text { Finding patterns or properties of } \\
\text { mathematical phenomena to make }\end{array}$ & 22 & 20 \\
a generalization & & \\
\hline Draw a conclusion & 18 & 18 \\
\hline
\end{tabular}

Table 5. Qualitative value of mathematical reasoning skills

\begin{tabular}{cccc}
\hline Score & $\mathbf{f}_{\mathbf{1}}$ & $\mathbf{f}_{\mathbf{2}}$ & $\mathbf{f}_{\text {tot }}$ \\
\hline $81-100$ & 8 & 5 & 13 \\
$61-80$ & 12 & 13 & 25 \\
$41-60$ & 4 & 4 & 8 \\
$21-40$ & 1 & 2 & 3 \\
$0-20$ & - & 1 & 1 \\
\hline
\end{tabular}

Note:

$\mathrm{f}_{1}$ : The number of students in test number 1

$\mathrm{f}_{2}$ : The number of students in test number 2

$\mathrm{f}_{\text {tot: }} \mathrm{f}_{1}+\mathrm{f}_{2}$

Table 6. Average students' mathematical reasoning skills

\begin{tabular}{ccccc}
\hline Score & f tot & $\mathbf{x i}_{\mathbf{i}}$ & $\mathbf{f}$ tot. $\mathbf{x}$ i & Average \\
\hline $81-100$ & 13 & 90,5 & 1176,5 & 68,89 \\
$61-80$ & 25 & 70,5 & 1762,5 & \\
$41-60$ & 8 & 50,5 & 404 & \\
$21-40$ & 3 & 30,5 & 91,5 & \\
$0-20$ & 1 & 10 & 10 & \\
Total & $\mathbf{5 0}$ & & $\mathbf{3 4 4 4 , 5}$ & \\
\hline
\end{tabular}

Based on the table above, the average mathematical reasoning skills after the implementation of the learning process using video media with the PMRI approach and collaborative learning on number pattern material for class VIII.A SMP Srijaya Negara Palembang is categorized as good.

\section{Discussion}

The implementation of this learning process has used video media and has been adapted to the principles and characteristics of PMRI and collaborative learning. According to Meitrilova and Putri (2020), PMRI is one solution to help students understand learning materials. The PMRI approach can make learning more interesting because learning begins with a real context for students (Putri, 2015). It acts as a bridge from contextual problem to formal mathematic (Trisnawati et al., 2015). The principles of PMRI have guided reinvention/progressive mathematizing, didactical phenomenology, and self-developed models; while the characteristics of PMRI are using contextual problems, using models, student contributions, interactivity, and is integrated with other learning topics (Zulkardi \& Putri, 2010). In 
collaborative learning, students are formed into several groups, with each member consisting of four people. Then, a video media is given that contains the problem of sharing tasks and jumping tasks (Wikanta, 2017). The problem is related to real problems following PMRI, a theory based on real problems (Zulkardi \& Putri, 2010). According to Rahayu and Putri (2021), the learning process involving the context makes students learn meaningfully. Students who do not understand this activity must dare ask for help from friends who already understand by saying, "Please teach me" (Sato, 2014). Giving problems through this video media can make students not feel bored and feel happy, this is because video media is included in the type of audio-visual media, namely media that uses the senses of hearing and sight, so when participating in learning can make students not feel bored and feel happy (Hadi, 2017).

Furthermore, students are given mathematical reasoning skills test questions at the next meeting. Mathematical reasoning skills are the skills to process mathematical thinking to get logical conclusions based on existing or appropriate methods, concepts, and facts or data (Munawaroh et al., 2019). The test questions that have been made have been adjusted to the indicators of mathematical reasoning skills, which consist of submitting a conjecture, finding patterns or properties of mathematical phenomena to generalize, and drawing a conclusion. Based on the results of the research findings described above, the indicators of students' mathematical reasoning skills that appear after learning using video media through the PMRI approach and collaborative learning will be explained in more detail as follows:

\section{Submit a conjecture}

Based on the student's answer test results, it can be seen that the most indicator that appears is the indicator of proposing allegations, namely that all students who take the test, 25 students, can bring up this indicator for test number one. In contrast, for test question number two, there are 23 students. According to Jannah et al. (2020), proposing an allegation is a student's effort to propose an allegation of the possibilities to obtain a solution to the given problem. It means that the student's efforts to make assumptions to get a solution have been good.

\section{Finding patterns or properties of mathematical phenomena to make a generalization}

For this second indicator, quite many students can bring up this indicator, namely 22 students for test question number one and 20 students for test question number two. Because of the limited time given to do it, many students have not come up with this second indicator ideally. According to Melani and Sutirna (2019), finding patterns or properties of mathematical phenomena to generalize is a skill that students have in finding patterns to be developed into mathematical sentences.

\section{Draw a conclusion}

For indicators that rarely appear are indicators of concluding, whereas, for test questions numbers 1 and 2, only 18 students bring up this indicator. However, VA students have been able to conclude completely and correctly based on the results of the interviews. However, VA 
students forget to write conclusions on the answer sheet due to the limited processing time given. VA students do not come up with indicators for concluding. Students are said to be able to bring up indicators of concluding if they produce new statements based on existing statements so that they can make conclusions following the question, following Afandi's (2016) statement.

It can be seen that after the learning process was carried out using video media with the PMRI approach and collaborative learning, it was found that the students' mathematical reasoning skills were classified as good. However, there were still students who did not display their mathematical reasoning skills indicators perfectly.

\section{Conclusion}

The mathematical reasoning skills of class VIII students on number pattern material after learning using video media through the PMRI approach and collaborative learning are classified as good with the indicator of submitting a conjecture as to the indicator that appears the most, is based on the research result. The indicator that appears the least in this study is to conclude because students still forget to write conclusions. After all, the time given is limited. Using video media through the PMRI approach and collaborative learning during learning can make students have good mathematical reasoning skills. However, the research conducted still has shortcomings, namely the weakness in contextual problems (sharing task) created by researchers in weight loss. Namely, if the pattern continues, it will become a problem. Therefore, it is better to set a target or normal weight limit so that the activity can be used properly. In addition, the limited time to work on the questions given by the researchers made students less than optimal at solving them.

\section{Acknowledgment}

This article is part of a research project funded by a professional research grant from the Universitas Sriwijaya with the letter number of the Chancellor's letter number 0014/UN9/SK.LP2M.PT/2021 with the research contract number 0127/UN9/SB3.LP2M.PT/2021.

\section{Conflicts of Interest}

The authors declare that the publication of this manuscript does not constitute a conflict of interest. In addition, everything has been borne by the author, namely ethical issues, including, plagiarism, errors, falsification and/or falsification of data, publication and/or duplicate submissions, and redundancy. 


\section{References}

Aeni, N., \& Yuhandini, D. S. (2018). The effect of health education with video media and demonstration methods on BSE knowledge. Journal of Care, 6(2), 162-174. https://doi.org/10.33366/cr.v6i2.929

Afandi, A. (2016). Junior high school students' deductive reasoning in solving geometric problems based on gender differences. Education and Human Development Journal, 1(1), 9-21. https://doi.org/10.33086/ehdj.v1i1.284

Ariyanti, S. N., \& Setiawan, W. (2019). Analysis of the difficulties of class VIII junior high school students in solving number pattern problems based on mathematical reasoning abilities. Journal On Education, 1(2), 390-399.

Bidasari, F. (2017). The development of PISA model math problems on quantity content to measure the mathematical problem-solving ability of junior high school students. Hanging Journal, 2(1), 63-78.

Cahya, I. M., Effendi, K. N. S., \& Roesdiana, L. (2021). The effect of independent learning on the mathematical reasoning ability of junior high school students. ANARGYA: Scientific $\begin{array}{llll}\text { Journal of } & \text { Mathematics }\end{array}$ https://doi.org/10.24176/anargya.v4i1.6080

Deswita, H., \& Niati, B. (2020). Analysis of the needs of collaborative learning-based mathematics English textbooks for mathematics education students. Edumatica Journal of Mathematics Education, 10(2), 57-63. https://onlinejournal.unja.ac.id/edumatica/article/download/10446/version/16246/6539/28595

Dewi, N. P. W. P., \& Agustika, G. N. S. (2020). The effectiveness of learning mathematics through the PMRI approach to the competence of mathematical knowledge. Journal of Educational Research and Development, 4(2), 204-214. https://doi.org/10.23887/jppp.v4i2.26781

Diana, F., \& Fauzan, A. (2018). Development of learning design for the topic of number patterns based on realistic mathematics education (RME) in class VIII SMP/MTS. Journal of Mathematics Education and Research, 7(4), 43-52. http://ejournal.unp.ac.id/students/index.php/pmat/article/download/5566/2888

Erissa, Ibrahim, B., \& Iqbal. (2018). The application of everyone is a teacher here to improve students' mathematical communication at SMP Negeri 10 Langsa. Scientific Journal of $\begin{array}{llll}\text { Mathematics } & \text { Education } & \text { Students, } & \text { 8-16. }\end{array}$ https://www.journal.iainlangsa.ac.id/index.php/kindi/article/view/841/584

Fatimah, A. E. (2016). Improving mathematical problem-solving ability and independent learning of SMK Negeri 1 Percut Sei Tuan students through a differentiated instruction approach. MES (Journal of Mathematics Education and Science), 2(1), 11-23.

Febriani, C. (2017). The effect of video media on learning motivation and cognitive learning outcomes in science learning in fifth grade elementary school. Prima Edukasia Journal, 5(1), 11-21. https://doi.org/10.21831/jpe.v5i1.8461

Firmadani, F. (2020). Technology-based learning media as a learning innovation in the 4.0 industrial revolution era. Copen: National Education Conference, 2(1), 93-97. http://ejurnal.mercubuanayogya.ac.id/index.php/Prosiding_KoPeN/article/view/1084/660

Hadi, S. (2017). The effectiveness of using video as a learning medium for elementary school students. Presented in the National Seminar on Learning Technology and Basic Education, Semarang State University. http://pasca.um.ac.id/conferences/index.php/sntepnpdas/article/view/849/521

Inah, E. N., \& Pertiwi, U. A. (2017). The application of collaborative learning through picturefinding games to improve science learning outcomes for class V at SDN Tabanggele, 
Anggalomoare District, Konawe Regency. Journal of Al-Ta'dib, 10(1), 19-36.

Isti'adah, et al. (2020). Utilization of technology as a learning medium in guidance and counseling services during the adaptation period of new habits. Presented at the National Seminar on Research Results and Community Service V, 2020, LPPM-University of Muhammadiyah Purwokerto. https://semnaslppm.ump.ac.id/index.php/semnaslppm/article/download/151/146

Jannah, R., Zubainur, C. M., \& Syahjuzar. (2020). The ability of students to make assumptions and to manipulate mathematics through the discovery learning model in Aceh middle school. Scientific Journal of Mathematics Education Students, 5(1), 70-78. http://jim.unsyiah.ac.id/pendidikan-matematika/article/view/14108/6396

Kemendikbud. (2016). Minister of education and culture regulation number 21 of 2016 concerning content standards for primary and secondary education. Kemendikbud.

Lisa. (2020). The effect of a realistic mathematics education approach on the problem-solving ability of elementary school students in North Aceh. Al-Gurfah: Journal of Primary Education, 1(1), 58-75. https://jurnal.iain-bone.ac.id/index.php/algurfah/article/view/219

Meitrilova, A., \& Putri, R. I. I. (2020). Learning design using PMRI to teach central tendency materials. Journal of Physics: Conf. Series, 1470(1), Article 012086. https://doi.org/10.1088/1742-6596/1470/1/012086

Melani, F., \& Sutirna. (2019). Analysis of mathematical reasoning abilities of VIII grade junior high school students on the material of relations and functions. Presented at the National Seminar on Mathematics and Mathematics Education (SESIOMADIKA), Singaperbangsa Karawang https://journal.unsika.ac.id/index.php/sesiomadika/article/view/2384/1846

Munawaroh, A., Surahmat, \& Fathani, A. H. (2019). The ability to reasoning and solving mathematical problems through the learning model (AIR) using mind mapping media on integer material for class VII SMP Salahuddin Malang. JP3, 14(8), 91-99. https://doi.org/10.30736/voj.v3i1.344

Munir, M., \& Sholehah H. (2020). Indonesian realistic mathematics learning (PMRI) in improving problem solving skills. Journal of Al-Muta'aliyah STAI Darul Kamal NW Kembang Kerang, 5(1), 33-42.

Narmi, et al. (2020). The effectiveness of a realistic approach to mathematics education is viewed from the mathematical problem-solving ability of students. Journal of Teaching and Learning Research, 2(2), 27-34. https://ejournal.iainpalopo.ac.id/index.php/JTLR/article/download/1731/1359

NCTM. (2000). Principles and standards for school mathematics. Reston, VA: Author. https://www.nctm.org/uploadedFiles/Standards_and_Positions/PSSM_ExecutiveSumma ry.pdf

Octriana, I., Putri, R. I. I., \& Nurjannah. (2019). Students' mathematical reasoning in learning number patterns uses PMRI and LSLC. Journal of Mathematics Education, 13(2), 131142. https://doi.org/10.22342/jpm.13.2.6714.131-142

Putri, R. I. I. (2015). The effect of the interaction of learning approaches and forms of formative tests on mathematics learning outcomes. Journal of Education and Learning (JPP), 22(1), 69-75. http://journal.um.ac.id/index.php/pendidikan-danpembelajaran/article/view/7723/3543

Rahayu, P.T., \& Putri, R. I. I. (2021). The data package in learning mean using LSLC and PMRI. Journal of Mathematics Education, 15(1), 61-70. https://doi.org/10.22342/jpm.15.1.9431.61-70

Rahmawati, K. (2016). The development of e-learning based on moodle as a learning resource for social studies at SMP class VII sub-themes of economic activities and utilization of natural resource potential. Journal of Social Research, 5(5), 1-10. 
https://adoc.tips/download/developing-e-learning-based-moodle-as-source-belaj.html

Saleh, A. N. A., Husniati, A., \& Gaffar, A. (2021). Analysis of the difficulty of solving math problems with number pattern material in terms of gender differences in class VIII SMP Negeri 34 Makassar. SIGMA: Journal of Mathematics Education, 13(1), 19-25.

Saleh, A., \& Lubis, F. A. (2018). The effect of using the make a match learning model on the mathematical problem solving ability of SPLDV subject matter in class VIII of SMP Negeri 1 Batang Angkola. Journal of Education and Development, 6(1), 20-26. https://journal.ipts.ac.id/index.php/ED/article/download/464/222/

Salsabilla, A. (2020). Implementation of the Indonesian realistic mathematics education approach (PMRI) to improve students' problem-solving abilities. Indonesian Journal of Education and Learning Mathematics (IJELM), 1(1), 9-12. http://ejournal.stkipmodernngawi.ac.id/index.php/IJELM/article/view/204/113

Sari, N. I. P., Subanji, \& Erry, H. (2018). Diagnosis of students' mathematical reasoning errors in solving number pattern problems. Journal of the Study of Mathematics Learning (JKPM), 2(2), 64-69. http://journal2.um.ac.id/index.php/jkpm/article/view/1065/3056

Sato, M. (2014). Dialogue and collaboration in junior high schools - the practice of "learning community". JICA.

Septikasari, R., \& Frasandy, R. N. (2018). 21st century 4C skills in basic education learning. $\begin{array}{llll}\text { Journal of Tarbiyah } & \text { 8l-Awlad, } & 112-122 .\end{array}$ https://ejournal.uinib.ac.id/jurnal/index.php/alawlad/article/view/1597/1196

Situmorang, K., Putri, R. I. I., \& Lelyana, C. K. (2020). The students' HOTS analysis on the number pattern material uses the PMRI approach through the LSLC system. Journal of Elements, 6(2), 333-345. https://doi.org/10.29408/jel.v6i2.2213

Sumantri, B. A. (2019). Curriculum development in Indonesia faces the demands of 21st century competence. el-HIKMAH Journal of Islamic Education Studies and Research, 13(2), 146-167. https://doi.org/10.20414/elhikmah.v13i2.661

Sumartini, T. S. (2015). Improving students' mathematical reasoning skills through problembased learning. Journal of Mathematics Education, 5(1), 1-10. https://journal.institutpendidikan.ac.id/index.php/mosharafa/article/view/mv4n1_1/244

Trisnawati, D., Putri, R. I. I., \& Santoso, B. (2015). The learning design for the surface area of a prism uses the PMRI approach for class VIII students. Journal of Creative-Innovative Mathematics (Kreano), 6(1), 76-85. https://doi.org/10.15294/kreano.v6i1.4504

Wikanta, W. (2017). Collaborative learning: Innovative learning in realizing students' learning rights. Pedagogy. Biol. J. Educator. and n. a. Biol, 5(1), 64-73.

Zulkardi, \& Putri, R. I. I. (2010). Development of a support blog to help Indonesian mathematics students and teachers learn Indonesian Realistic Mathematics Education (PMRI). Journal of Educational Engineering and Innovation Research, 2(1), 1-24. http://repository.unsri.ac.id/id/eprint/6777 